УДК 317:34

DOI: $10.31470 / 2518-7600-2019-6 / 2-77-94$

\author{
STRUCTURE OF THE UNIVERSITY \\ EXTRACURRICULAR WORK AND ITS ROLE IN \\ PREPARATION OF FUTURE PSYCHOLOGISTS
}

\title{
СТРУКТУРА ПОЗААУДИТОРНОЇ РОБОТИ ТА П̈І РОЛЬ У ПІДГОТОВЦІ МАЙБУТНІХ ПСИХОЛОГІВ
}

\section{Андрій Іващенко,}

кандидат педагогічних наук, доцент кафедри

документознавства,

e-mail: socgum_phdpu@ukr.net

ДВНЗ «Переяслав-

Хмельницький державний

педагогічний університет

імені Григорія Сковороди»,

м. Переяслав-Хмельницький, вул. Сухомлинського, 30, Київська обл., Україна, 08401
Andrii Ivashchenko, Candidate of Pedagogic Sciences

Associate Professor of

Department of scientific discipline of documentation e-mail:

socgum_phdpu@ukr.net Pereiaslav-Khmelnytskyi Hryhorii Skovoroda State Pedagogical University, 30, Sukhomlynsky Str., Pereiaslav-Khmelnytskyi, Kyiv region, Ukraine, 08401

\section{Альона Іващенко,}

викладач кафедри

менеджменту

освіти і практичної психології, e-mail: alyona.ger@ukr.net ДВН3 «Переяслав-

Хмельницький державний педагогічний університет імені Григорія Сковороди», м. Переяслав-Хмельницький, вул. Сухомлинського, 30, Київська обл., Україна, 08401

\section{Aliona Ivashchenko,} teacher of the Department of Management of Education and

Practical Psychology e-mail: alyona.ger@ukr.net Pereiaslav-Khmelnytskyi Hryhorii Skovoroda State Pedagogical University, 30, Sukhomlynsky Str., Pereiaslav-Khmelnytskyi, Kyiv region, Ukraine, 08401 


\section{ABSTRACT}

The article deals with the concept of "University extracurricular work», it is studied as a special form of organization of student life extra schedule of classes in high school on the principles of interest and voluntariness that creates conditions for personal development and creative self-realization of future psychologists.

Extracurricular work is a logical continuation of auditory classes and runs alongside them. It helps to study successfully, develops initiative, promotes mental, physical, aesthetic growth, satisfies cultural demands, and directs energy to the creative beneficial activities of students, in particular future psychologists. In our opinion, it has the most effective impact on the value orientation of personal self-development of future psychologists. The importance of extracurricular work on the personal selfdevelopment of future psychologists is caused by the fact that it is based not on coercion, but on the principles of voluntariness, taking into account their interests, abilities and aspirations. However, in modern conditions in the organization of non-auditing work of higher education, the influence on the personal self-development of students due to lack of development of its content and methodological support is not a priority.

In the process of theoretical analysis of the peculiarities of the structure of future psychologists' extracurricular work, the following components were identified: cultural-leisure activity on interests, sports and recreation activities, independent educational activities, student self-government. It was found out that the following types of extracurricular activities are distinguished by the number of participants: individual, group, mass and complex. The nature of the non-auditing work of the University promotes the practical application of such methods: interactive, problem, project, methods of stimulation and motivation, self-control and selfeducation etc.

Extracurricular work contributes to formation of the moral qualities of future psychologists, development of their creative potential, formation of a personal style of behavior, development of the need and skills of self-education, breeding of healthy lifestyles, development of strong-willed, leadership and organizational qualities. 
Keywords: extracurricular work, self-development, selfeducation, leisure, creativity, student self-government.

Постановка проблеми. На сучасному етапі розвитку української держави вища освіта спрямована не лише на якісну професійну підготовку фахівця, а й на всебічний розвиток особистості. Позааудиторна робота є логічним продовженням аудиторних занять і проходить паралельно з ними. Вона допомагає успішно навчатись, розвиває ініціативу, сприяє розумовому, фізичному, естетичному зростанню, задовольняє культурні запити та спрямовує енергію на творчу корисну діяльність студентів, зокрема майбутніх психологів. На нашу думку, вона має найбільш ефективний вплив на ціннісну спрямованість особистісного саморозвитку майбутніх психологів. Значення позааудиторної роботи щодо особистісного саморозвитку майбутніх психологів зумовлене тим, що вона грунтується не на примусі, а на принципах добровільності, врахуванні їхніх інтересів, здібностей та прагнень. Проте у сучасних умовах в організації позааудиторної роботи вищої школи, вплив на особистісний саморозвиток студентів через недостатню розробку ії змістової сторони й методичного забезпечення займає не пріоритетне місце.

Аналіз досліджень і публікацій. У нашому дослідженні першочергову увагу варто приділити структурі позааудиторної роботи експериментальних вищих навчальних закладів за кордоном, яка вирізняється неабиякою різноманітністю. Так, у структурі позанавчальної роботи зі студентами американських вищих навальних закладів М. Мартинова виокремлює складники із врахуванням традицій американської культури, особливостей американської вищої освіти, а також прагматичних інтересів громадян. Складовими позанавчальної роботи, за її поглядами є інтенсивне спортивне життя, система кураторської роботи зі студентами, робота в гуртожитках, робота 3 студентами щодо формування дисципліни та їх відповідність «Кодексу Студентської Поведінки», охорона студентського здоров'я, діяльність студентського правління, студентських суспільних організацій, волонтерська робота, 
лідерські програми забезпечення умов задоволення потреб віруючих студентів, студентська преса, підтримка талановитих і обдарованих студентів, програма підтримки та забезпечення культурного відпочинку, консультаційна психологічна допомога, робота з батьками й сім'ями студентів, допомога у працевлаштуванні (Мартинова, 2003). Д. Боков зазначав, що різноманітність видів позанавчальної діяльності вищих навчальних закладів представлена також досить широко, через це існує багато підходів стосовно іï практичної реалізації, що викликає чимало труднощів, причому як об'єктивного, так i суб'єктивного характеру, для подолання яких необхідно враховувати досвід як зарубіжних так і вітчизняних вчених. Однак, на його думку, повне копіювання будь-якого досвіду недоцільне, оскільки кожна країна, а, зокрема, кожен вищий навчальний заклад мають свою специфіку, яка впливає і на позанавчальну діяльність.

Водночас С. Савченко пропонує об'єднати все різноманіття видів позанавчальної діяльності у такі групи: науково-дослідна діяльність (проведення дослідів, робота в науковому товаристві, написання наукової статті, участь в експедиції, заняття в гуртках тощо, виконання конкретних програм і проектів); суспільно-політична діяльність (робота в органах студентського самоврядування, участь у виборчих кампаніях, співпраця з молодіжними організаціями, діяльність у студентських об'єднаннях); художньо-естетична діяльність (участь у художній самодіяльності, КВН, різноманітних творчих гуртках, літературна, художня творчість, захоплення різними видами мистецтва); трудова (частково-трудова) діяльність (робота у волонтерському загоні, участь у будзагонах, практика, різні види комерційно-трудової діяльності); історико-культурна й етнографічна діяльність (заняття у національно-культурних гуртках і об'єднаннях, фольклорні, історико-культурні експедиції, вивчення забороненої і забутої літературної спадщини земляків); фізкультурно-спортивна діяльність (відвідування спортивних гуртків, секцій, участь у спортивних змаганнях, заняття спортом поза вищим навчальним закладом, спортивний історико-культурний туризм, професійний спорт тощо.); 
організаційно-управлінська діяльність (специфічний вид діяльності, яким займається невелика за кількістю група активістів, котрі безпосередньо є лідерами студентства в масштабах вищого навчального закладу, району, регіону) (Савченко, 2003). Разом з тим, позанавчальна діяльність у вищому навчальному закладі, як стверджував Г. Овчаренко, здійснюється за такими основними напрямами: науководослідницьким, суспільно-політичним, художньо-естетичним, трудовим, історико-культурним й етнографічним, фізкультурно-спортивним, організаційно-управлінським. У структурі системи позааудиторної виховної роботи В. Коваль виокремлював такі складники: самостійна навчальна робота студентів; діяльність з самоврядування студентського колективу; культурно-дозвіллєва діяльність за інтересами; підвищення професійної майстерності. Вчений вбачає зміст позааудиторної діяльності студентів у $\ddot{i x}$ участі $в$ студентському самоврядуванні, творчій груповій діяльності, культурно-дозвіллєвій та спортивно-оздоровчій роботі (Коваль, 2013). На думку Н. Скрипник, позааудиторна діяльність студентів має таку структуру: самостійна навчальна робота студентів; навчально-дослідна та науково-дослідна робота; культурно-дозвіллєва діяльність; студентське самоврядування. Водночас основними компонентами системи позааудиторної роботи у вищій школі Л. Петриченко визначає науково-дослідну роботу студентів, професійно спрямовану виховну позааудиторну роботу та студентське самоврядування (Курлянд, 2005).

Метою написання статті с теоретичний аналіз особливостей структури позааудиторної роботи майбутніх психологів.

Виклад основного матеріалу. Аналіз сучасних наукових праць (Д. Боков, В. Коваль, М. Мартинова, Г. Овчаренко, Л. Петриченко, С. Савченко, Н. Скрипник та ін.) та врахування особливостей позааудиторної роботи в експериментальних університетах дозволили нам виділити такі їі складові: культурно-дозвіллева діяльність за інтересами, спортивнооздоровча діяльність, самостійна навчально-наукова діяльність, студентське самоврядування. 
Культурно-дозвіллєва діяльність за інтересами передбачає організацію дозвілля та вільного часу студентської молоді у процесі позааудиторної роботи вищих навчальних закладів. Учені стверджують (С. Брайтбілл, Д. Вайскопф, Б. Геба, Х. Раскін, Дж. Неш та інші), що спосіб використання людиною свого вільного часу детермінує соціальний та культурний розвиток суспільства в якому вона живе. Педагогічний процес у сфері дозвілля, на думку I. Петрової, становить цілеспрямовану організацію дозвіллєвої діяльності та іiї систематичне вдосконалення з урахуванням характерних ознак та потреб особистості (Петрова, 2005).

Дж. Шиверс вважає доцільним поділ дозвілля на такі групи: дозвілля як рекреація (коли воно сприймається виключно як діяльність, що допомагає людині набути рівноваги в організмі); дозвілля як задоволення (коли основною мотивацією дозвіллєвої діяльності є отримання радості); дозвілля як відновлення сил (коли дозвілля вважається засобом відновлення здоров'я людини, його духовних та фізичних сил); дозвілля як стан буття (сфера життєдіяльності, у якій людина може самореалізуватися та розвинути свої здібності); дозвілля як функція (окремі відрізки часу, коли людина самоудосконалюється та розвивається); дозвілля як соціальна стратифікація (дозвілля залежить від того, виразником якого соціального класу є індивід); дозвілля як вільний час (що залишається для людини після виконання нею робочих обов'язків). Цікавою для вивчення дозвілля $є$ й концепція Р. Стеббінса, який поділяє дозвілля на серйозне та звичайне. Серйозним дозвіллям, на його думку, є стійкі заняття любителів або учасників громадської (само) діяльності, які захоплюють людину численними можливостями й характерною для них комплексністю (хобі, волонтерство тощо). На думку автора звичайне дозвілля відрізняється від серйозного дозвілля; оскільки приносить користь саме по собі, як відносно нетривала приємна діяльність, що вимагає незначного або не вимагає ніякого спеціального навчання, щоб отримати задоволення. Його типи включають гру, розслаблення (наприклад, посиденьки, денний сон, прогулянки), пасивні розваги (телебачення, книги, музичні записи) і активні розваги (ігри, розіграші на вечірках) тощо (Стеббінс, 2000). 
Зважаючи на множинність та різноманітність класифікацій дозвілля, у нашому дослідженні використана класифікація дозвілля за такими ознаками: видом активності (пасивне та активне дозвілля); періодичністю (щоденне, щотижневе, відпусткове, святкове); тривалістю (короткочасне, довготривале, епізодичне); напрямами діяльності (творче, рекреаційне, культурне, спортивне, декоративно-прикладне, туристичне) (Петриченко, 2007). Особлива увага у процесі дослідження приділена творчому дозвіллю. І. Шевчук підкреслював, що «активне творче дозвілля сприяє формуванню почуття щастя, зникненню депресії, покращенню настрою. Молодь сприймає дозвілля як основну сферу життєдіяльності. I від задоволеності нею залежить загальна задоволеність життям» (Шевчук, 2009). Культурно-дозвіллєва діяльність передбачає участь майбутніх психологів у різноманітних виховних заходах університету та об'єднаннях різного типу й напряму, конкурсах, змаганнях та ін.

Спортивно-оздоровча діяльність є найважливішим аспектом позааудиторної роботи університету. Особливо важливою вона $є$ у справі виховання майбутніх психологів, оскільки в їх роботі чільне місце займає власний приклад. Зважаючи на це, можна сказати, що формування здорового способу життя майбутніх психологів - це запорука здоров'я нації. Економічний, соціальний та інтелектуальний потенціал Української держави, здоров'я нинішнього й подальшого поколінь значною мірою визначаються кількісними і якісними характеристиками здоров'я, якими сьогодні володіє молодь. Тому впорядкування цілісного процесу формування здорового способу життя та проведення спортивно-оздоровчої діяльності $\epsilon$ важливим напрямом позааудиторної роботи університету. Окремі аспекти формування здорового способу життя розглядають учені різних галузей: філософи - Е. Бабаян, Е. Бахтель; психологи - В. Бітенський, М. Бурно, А. Личко; соціологи - А. Габіані, Я. Гданський, С. Дідковський; медики Г. Апанасенко, Т. Бойченко та ін. Загальні теоретичні питання здорового способу життя розглянуто в роботах А. Апанасенко, С. Бондаревського, О. Дубогай та ін.; змістовий бік проблеми виховання навичок здорового способу життя докладно 
розкривається В. Артемоновим, В. Моченовим, Р. Баєвським та ін. Також проблему формування здорового способу життя студентів у період їх навчання у вищих навчальних закладах розглядали у своїх дослідженнях М. Амосов, I. Брехман, В. Петленко, Р. Баєвський, В. Бальсевич, М. Віленський, В. Волков, П. Ключик та ін. (Санфирова, 2003).

Спортивно-оздоровча діяльність проводиться зі студентами у процесі позааудиторної роботи університету під час спортивних змагань, олімпіад, профілактичної санітарнолікувальної заходів, спортивно-розважальних програм, зустрічей 3 відомими спортсменами тощо. 3 урахуванням особливої важливості спортивно-оздоровчої діяльності у житті студентської молоді виникає необхідність використання різних здоров'язберігаючих технологій в організації всієї позааудиторної роботи університету.

Сучасна система навчально-наукової діяльності вищого навчального закладу має бути особистісно зорієнтованою, спрямованою на виховання наукової культури особистості 3 максимально можливою індивідуалізацією, створенням умов для творчої самореалізації, утвердженням професійної етики. В університеті створюється наукове середовище, яке сприяє формуванню й розвитку у студентів науково-дослідницьких умінь, залученню їх до активної самостійної наукової діяльності. Науково-дослідницька робота студентів у позанавчальний час виступає продовженням навчальнодослідницької і є ефективним засобом об'єктивного вияву обдарованої студентської молоді, реалізації ऑï творчих здібностей, стимулювання потреби у творчому оволодінні знаннями, активізації навчально-пізнавальної діяльності. Серед форм наукових досліджень, до яких залучаються студенти в позанавчальний час, виділяються гуртки, проблемні групи, дискусійні клуби, конкурси, конференції, олімпіади тощо. Початковою формою позааудиторної наукової роботи $\epsilon$ предметні гуртки, мета яких - ознайомлення із проблематикою науки, глибше вивчення окремих питань цієї науки, опанування принципів, методів, прийомів ведення наукової роботи, формування у студентів основних навичок, необхідних для подальшої самостійної роботи. Такі гуртки можуть бути 
започатковані в кожній студентській групі за допомогою кураторів за умов наявності в останніх необхідного рівня наукової та педагогічної підготовки.

Студенти старших курсів працюють у проблемних групах під керівництвом викладача, виконують критичний аналіз існуючих наукових концепцій, збирають i обробляють емпіричний матеріал, опановують методологію i логіку наукового дослідження. Кращі студентські роботи після обговорення їх на засіданні групи за рекомендацією керівника та випускової кафедри пропонуються на студентську конференцію, конкурс чи олімпіаду.

Студентське самоврядування розуміємо як самостійне розв'язання проблем життєдіяльності студентської групи, колективу гуртожитку тощо. Студентське самоврядування форма управління, за якої студентство має право самостійно вирішувати питання внутрішнього управління, або виборна установа, що здійснює таке управління; право студентства самостійно вирішувати питання внутрішнього управління, а також мати свої керівні органи.

Особливий інтерес для нашого дослідження становлять сучасні наукові праці таких вітчизняних учених як Л. Божович, О. Дубасенюк, I. Бех, А. Капська, В. Караковський, Т. Кириленко, Т. Кірова, В. Семиченко, С. Сисоєва та інших, у яких розглядаються організаційні аспекти самоврядування, проблеми соціальної зрілості та самореалізації, дотримання гуманістичних цінностей, формування здатності до свідомої саморегуляції. Так, участь студентів у вільний від навчання час у самоврядуванні Т. Кірова характеризувала як участь у позанавчальній діяльності. Студентське самоврядування на зазначеному рівні можна уявити, на думку вченої, як процес перетворення студента 3 об'єкта управлінської діяльності в їі суб'єкт, як механізм, що є реальною формою студентської демократії та засобом соціально-правового самозахисту студентів. Воно виконує умови реалізації творчої активності, спрямованої на саморозвиток, самореалізацію і самовиховання студентів вищих навчальних закладів, тобто спрямований на системну організацію студентського життя (Кирова, 2009). А. Волохов та М. Рожков розглядали поняття «студентське 
самоврядування» як форму організації життєдіяльності студентських колективів, що забезпечує розвиток самостійності у прийнятті та реалізації рішень для досягнення суспільно значущих цілей (Петрова, 2005).

Варто зазначити, що органи студентського самоврядування мають право приймати акти, що регламентують їхню організацію та діяльність; проводити організаційні, наукові, культурно-масові, спортивні, оздоровчі та інші заходи; сприяти працевлаштуванню осіб, які навчаються в інститутах та університетах; розпоряджатися коштами й іншим майном, що знаходяться на їхньому балансі та банківських рахунках та багато іншого.

До того ж, за погодженням 3 органом студентського самоврядування приймаються рішення: про відрахування осіб, які навчаються у вищому навчальному закладі, та їх поновлення на навчання; про переведення осіб, які навчаються у вищому навчальному закладі за державним замовленням, на навчання за контрактом за рахунок коштів фізичних i юридичних осіб; про переведення осіб, які навчаються у вищому навчальному закладі за контрактом за рахунок коштів фізичних i юридичних осіб, на навчання за державним замовленням; про призначення заступника декана, проректора, які відповідають за роботу зі студентами; про поселення осіб, які навчаються у вищому навчальному закладі, у гуртожиток i виселення 3 нього; про затвердження рішень 3 питань студентських містечок і гуртожитків для проживання осіб, які навчаються у вищих навчальних закладах.

Весь процес самоорганізації публічного життя студентської молоді регламентується Лімською декларацією «Про академічну свободу та автономію вищих навчальних закладів» (1988 р.), яка проголошує право на «...свободу думки, совісті, віросповідання, слова, зборів і об'єднань»; «участь студентів у своїх органах управління, особисто або колективно...»; «...свободу об’єднань.., включаючи право створювати і ставати членами професійних спілок для захисту своїх інтересів».

Отже, виходячи 3 аналізу наукової літератури й сучасних нормативних документів, поняття «студентське самоврядування» варто трактувати так: 
- це реальна форма студентської демократії з відповідними правами, повноваженнями й відповідальністю;

- це засіб (ресурс) соціально-правового самозахисту;

- це умова реалізації творчої активності й самодіяльності студентів у навчально-пізнавальному, науково-професійному та культурному аспектах;

- це механізм, спрямований на саморозвиток, самореалізацію і самовиховання студентів у вищих навчальних закладах. Саме на таке тлумачення студентського самоврядування ми спираємось у нашому дослідженні.

Низка вчених, таких як В. Худяков, О. Семушина, Ф. Сімбірякова вважають позааудиторну діяльність одним із видів діяльності студентів, яка спрямована на творчий саморозвиток і самореалізацію особистості в позанавчальний час та підвищення якості їх професійної освіти, a, отже, їх професійної підготовки. Ці автори визначають позааудиторну діяльність як сукупність перетворювальних дій, скоєних за межами навчального процесу, які мають власну специфіку i логіку, властиві їй елементи, функції, принципи, зміст, форми і методи, критерії оцінки. Результати цих дій найефективніше впливають на професійне виховання в процесі взаємопов'язаної навчальної та позааудиторної діяльності студентів (Худяков, 2010). Враховуючи специфіку позааудиторної діяльності варто зупинитися на властивих їй формах і методах роботи.

Під організаційно-педагогічними формами позааудиторної діяльності вищих навчальних закладів розуміють види, способи організації студентів і викладачів для спільної діяльності в позанавчальний час, а також конкретні виховні заходи, розраховані на студентську аудиторію. Різні форми позааудиторної діяльності збільшують можливість успішного виконання завдання з удосконалення професійної підготовки майбутніх фахівців і досягнення позитивних результатів у формуванні професійно значущих рис і якостей особистості, що відповідають вимогам управлінської праці (Санфирова, 2012).

У сучасній психолого-педагогічній літературі (О. Киричук, Т. Ломидзе, В. Петрович, В. Стахневич та ін.) за 
кількістю учасників виділяють наступні форми позааудиторної діяльності: індивідуальні, групові, масові та комплексні. Індивідуальна робота включає конкретну діяльність студентів, спрямовану на самовиховання, виконання завдань викладача та доручень студентського колективу. Групова форма роботи сприяє виявленню та розвитку інтересів і творчих здібностей майбутніх психологів у позааудиторній діяльності, збагачує їх інформацією, досвідом творчої роботи, формує професійно значущі вміння й навички. Групова позааудиторна робота має цільовий характер і передбачає наявність групової визначеної мети та спільних інтересів студентів.

Найпоширенішою формою позааудиторної роботи у вищих навчальних закладах виступають форми масової роботи. Вони дуже різні й мають перевагу в тому, що розраховані на одночасне охоплення великої кількості студентів. Особливостями цієї форми позааудиторної роботи є яскравість, урочистість, значний емоційний вплив, можливість охопити велику кількість студентів. Комплексні форми позааудиторної роботи створюються шляхом інтеграції різних форм виховної роботи.

До масових форм позааудиторної роботи можна віднести такі: читацька конференція, тематичні вечори, зустрічі 3 видатними людьми, «круглі столи», олімпіади, екскурсії, вечори запитань та відповідей, вікторини тощо. Групові форми позааудиторної роботи включають гуртки художньої самодіяльності, творчі лабораторії, випуск стінної газети, телепередач, проведення походів, роботу студентських клубів, асоціацій, студій та центрів, підготовку вистав, концертів, театралізованих вечорів, фестивалів, тематичних лекторіїв та семінарів, проведення КВК, організацію дискусійних клубів та ін. До індивідуальних форм роботи можна віднести позааудиторне читання, науково-дослідницьку діяльність, колекціонування, заняття мистецтвом, заняття за інтересами 3 орієнтацією на розкриття їх творчого потенціалу.

Потреба у використанні тієї чи іншої форми позааудиторної роботи університету обумовлюється різними обставинами, потребами студентської молоді в самодіяльності, самореалізації та соціальному самовизначенні. Різні форми 
позанавчальної работи, як зауважує Д. Боков, сприяють розвитку таких властивостей особистості, як ініціативність, відповідальність, гуманізм, без яких неможливе визначення себе щодо вироблених у суспільстві й усвідомлено прийнятих ним критеріїв приналежності до тієї чи іншій сфери суспільних відносин і до того чи іншого соціального кола. Саме тому комплекс методів позааудиторної роботи університету повинен містити: інтерактивні методи (бесіди, ротації, тренінги, ділові та рольові ігри тощо); метод проектів (виконання різних проектів, особливо творчих); проблемні методи (дискусії, диспути, аналіз та обговорення проблемних ситуацій на професійні теми та інше); методи стимулювання й мотивації (заохочення, нагороди, похвала, критика тощо); методи самоконтролю самовиховання (самооцінка, самоаналіз, самокритика та ін.). Формування в комплексі зазначених форм і методів роботи підвищує результативність позааудиторної роботи університету.

Висновки. Отже, вивчення особливостей позааудиторної роботи майбутніх психологів дало нам можливість виділити в процесі теоретичного аналізу такі їі складники: культурнодозвіллєва діяльність за інтересами, спортивно-оздоровча діяльність, самостійна навчально-наукова діяльність, студентське самоврядування. 3'ясовано, що за кількістю учасників виділяють такі форми позааудиторної діяльності: індивідуальні, групові, масові та комплексні. Характер позааудиторної роботи університету сприяє практичному застосуванню таких методів: інтерактивних, проблемних, проектних, методів стимулювання й мотивації, самоконтролю та самовиховання тощо. Позааудиторна робота сприяє формуванню моральних якостей майбутніх психологів, розвитку їх творчого потенціалу, формуванню особистісного стилю діяльності та поведінки, розвитку потреби та навичок самоосвітньої діяльності, вихованню здорового способу життя, розвитку вольових, лідерських та організаторських якостей.

\section{ДЖЕРЕЛА ТА ЛІТЕРАТУРА}

1. Кирова Т. И. Профессионально-творческая самореализация будущих специалистов в области хореографии 
в условиях организации студенческого самоуправления // Мир науки, культуры, образования. 2009. № 6 (18). С. 183-186.

2. Коваль В.Ю. Виховання культури міжособистісних відносин студентів університету у позааудиторній діяльності: автореф. дис. на здобуття наукового ступеня канд. пед. наук: сп. 13.00.07 «Теорія і методика виховання». Умань, 2013. 20 с.

3. Мартынова М.Д. Система внеучебной работы со студентами в американском вузе // Вестник ВГУ (Серія: Проблемы высшего образования. 2003. №1. С. 34-42.

4. Педагогіка вищої школи / за ред. З.Н.Курлянд. К.: Знання, 2005.

5. Петриченко Л.О. Підготовка майбутнього вчителя початкової школи до іноваційної діяльності в позааудиторній роботі:автореф. дис. на здобуття наукового ступеня канд. пед. наук: сп. 13.00.04 «Теорія і методика професійної освіти». Кіровоград, 2007. 20 с.

6. Петрова І.В. Дозвілля в зарубіжних країнах. К.: «Кондор», 2005. 408 c.

7. Савченко С.В. Личностно-ориентированный подход к организации внеучебной работы в вузе // Вісник луганського державного педагогічного університету імені Тараса Шевченка. Педагогічні науки. 2003. №7 (63). С. 193-198.

8. Санфирова О.В. Знаниевая компонента в системе подготовки специалистов социально-культурной сферы и туризма в обществе устойчивого развития // Вестник ТГПУ. 2012. Вып. 12 (127). С. 182-189.

9. Стеббинс Р.А. Свободное время: к оптимальному стилю досуга (взгляд из Канады) // Социологические исследования. 2000. № 7. С. 64-72.

10. Худяков В. Н. Роль интеграции учебной и внеучебной деятельности в профессиональном воспитании студентов // Вопросы современной науки и практики (университет им. В. И. Вернадского). 2010. № 10-12 (31). С. 158-163.

11. Шевчук I. Дозвіллєва діяльність студентства як простір їх соціалізації // Вісник Львівського ун-ту (Серія: Педагогіка). 2009. Вип. 25. Ч. 2. С. 326-331. 


\section{REFERENCES}

1. Kirova, T. I. (2009). Professional'no-tvorcheskaya samorealizatsiya budushchikh spetsialistov v oblasti khoreografii v usloviyakh organizatsii studencheskogo samoupravleniya [ Professional and creative self-realization of future specialists in the field of choreography in the conditions of the organization of student government ] // Mir nauki, kul'tury, obrazovaniya. 6 (18). 183-186 [in Russian].

2. Koval, V.Yu. (2013). Vykhovannia kultury mizhosobystisnykh vidnosyn studentiv universytetu u pozaaudytornii diialnosti: avtoref. dys. na zdobuttia naukovoho stupenia kand. ped. nauk: sp. 13.00.07 "Teoriia i metodyka vykhovannia» [Education of the culture of interpersonal relations of university students in non-auditing activity: author's abstract. dis for obtaining a scientific degree of candidate. ped Sciences: sp. 13.00.07 «Theory and Methodology of Education»]. Uman. 20 [in Ukrainian].

3. Martynova, M.D. (2003). Sistema vneuchebnoy raboty so studentami v amerikanskom vuze [The system of extracurricular work with students in an American university] // Vestnik VGU (Seriya: Problemy vysshego obrazovaniya). 1. 34-42 [in Russian].

4. Pedahohika vyshchoi shkoly (2005). [ Pedagogy of higher education ] / za red. Z.N.Kurliand. K.: Znannia [in Ukrainian].

5. Petrychenko, L.O. (2007). Pidhotovka maibutnoho vchytelia pochatkovoi shkoly do inovatsiinoi diialnosti $v$ pozaaudytornii roboti [ Preparation of the future teacher of elementary school for innovative activity in non-auditing work]: avtoref. dys. na zdobuttia naukovoho stupenia kand. ped. nauk: sp. 13.00.04 «Teoriia i metodyka profesiinoi osvity». Kirovohrad. 20 [in Ukrainian].

6. Petrova, I.V. (2005). Dozvillia v zarubizhnykh krainakh [Leisure in foreign countries]. K.: «Kondor», 408 [in Ukrainian].

7. Savchenko, S.V. (2003). Lichnostno-orientirovannyy podkhod $k$ organizatsii vneuchebnoy raboty $v$ vuze [Personalityoriented approach to the organization of extracurricular work in high school] // Visnik lugans'kogo derzhavnogo pedagogichnogo universitetu imeni Tarasa Shevchenka. Pedagogichni nauki. 7 (63). 193-198 [in Ukrainian].

8. Sanfirova, O.V. (2012). Znanievaya komponenta v sisteme podgotovki spetsialistov sotsial'no-kul'turnoy sfery i turizma $\mathrm{v}$ 
obshchestve ustoychivogo razvitiya [Knowledge component in the system of training specialists in the socio-cultural sphere and tourism in the society of sustainable development] // Vestnik TGPU. V. 12 (127). 182-189 [in Ukrainian].

9. Stebbins, R.A. (2000). Svobodnoe vremya: k optimal'nomu stilyu dosuga (vzglyad iz Kanady) [Leisure time: to the optimal style of leisure (a look from Canada)] // Sotsiologicheskie issledovaniya. 7. 64-72 [in Russian].

10. Khudyakov, V. N. (2010). Rol' integratsii uchebnoy i vneuchebnoy deyatel'nosti v professional'nom vospitanii studentov [The role of integration of educational and extracurricular activities in the professional education of students] // Voprosy sovremennoy nauki i praktiki (universitet im. V. I. Vernadskogo). 10-12 (31). 158-163 [in Russian].

11. Shevchuk, I. (2009). Dozvillieva diialnist studentstva yak prostir yikh sotsializatsii [Leisure activity of students as a space of their socialization ] // Visnyk Lvivskoho un-tu (Seriia: Pedahohika). V. 25/2. 326-331 [in Ukrainian].

\section{АНОТАЦІЯ}

У статті розглядається поняття «позааудиторна робота університету», вона вивчається як особлива форма організації студентського життя поза розкладом занять у вищій школі на принщипах зацікавленості та добровільності, щзо створює умови для особистісного розвитку $і$ творчої самореалізації майбутніх психологів.

Позааудиторна робота є логічним продовженням аудиторних занять $і$ проходить паралельно $з$ ними. Вона допомагає успішно навчатись, розвиває інічіативу, сприяє розумовому, фізичному, естетичному зростанню, задовольняе культурні запити та спрямовує енергію на творчу корисну діяльність студентів, зокрема майбутніх психологів. На нашу думку, вона має найбільш ефективний вплив на ціннісну спрямованість особистісного саморозвитку майбутніх психологів. Значення позааудиторної роботи щуодо особистісного саморозвитку майбутніх психологів зумовлене тим, щуо вона трунтується не на примусі, а на принципах добровільності, врахуванні їхніх інтересів, здібностей та прагнень. Проте у сучасних умовах в організації 
позааудиторної роботи вищзої иколи, вплив на особистісний саморозвиток студентів через недостатню розробку ї змістової сторони й методичного забезпечення займає не пріоритетне місие.

В процесі теоретичного аналізу особливостей структури позааудиторної роботи майбутніх психологів було виокремлено такі ї складники: культурно-дозвіллєва діяльність за інтересами, спортивно-оздоровча діяльність, самостійна навчально-наукова діяльність, студентське самоврядування. З'ясовано, щзо за кількістю учасників виділяють такі форми позааудиторної діяльності: індивідуальні, групові, масові та комплексні. Характер позааудиторної роботи університету сприяє практичному застосуванню таких методів: інтерактивних, проблемних, проектних, методів стимулювання й мотивації, самоконтролю та самовиховання тощзо. Позааудиторна робота сприяє формуванню моральних якостей майбутніх психологів, розвитку їх творчого потенціалу, формуванню особистісного стилю діяльності та поведінки, розвитку потреби та навичок самоосвітньої діяльності, вихованню здорового способу життя, розвитку вольових, лідерських та організаторських якостей.

Ключові слова: позааудиторна робота, саморозвиток, самовиховання, дозвілля, творчість, студентське самоврядування.

\section{АННОТАЦИЯ}

В статье рассматривается понятие «внеаудиторная работа университета», она изучается как особая форма организации студенческой жизни вне расписания занятий в высшей школе на принципах заинтересованности $и$ добровольности, что создает условия для личностного развития и творческой самореализацчи будущцих психологов.

Внеаудиторная работа является логическим продолжением аудиторных занятий и проходит параллельно с ними. Она помогает успешно учиться, развивает инициитиву, способствует умственному, физическому, эстетическому росту, удовлетворяет культурные запросы и направляет энергию в творческую полезную деятельность 
студентов, в том числе будущих психологов. По нашему мнению, она имеет наиболее эффективное воздействие на ценностную направленность личностного саморазвития будущих психологов. Значение внеаудиторной работы для личностного саморазвития будущих психологов обусловлено тем, что она основывается не на принуждении, а на принципах добровольности, учете их интересов, способностей и стремлений. Однако в современных условиях в организачии внеаудиторной работь высшей школь, влияние на личностное саморазвитие студентов из-за недостаточной разработанности ее содержательной сторонь и методического обеспечения занимает не приоритетное место.

В проиессе теоретического анализа особенностей структуры внеаудиторной работы будущчих психологов было выделено такие ее составляющие: культурно-досуговая деятельность по интересам, спортивно-оздоровительная деятельность, самостоятельная учебно-научная деятельность, студенческое самоуправление. Установлено, что по количеству участников выделяют следуюшие формы внеаудиторной деятельности: индивидуальные, групповые, массовые и комплексные. Характер внеаудиторной работы университета способствует практическому применению таких методов: интерактивных, проблемных, проектных, методов стимулирования и мотивации, самоконтроля $и$ самовоспитания и тому подобное. Внеаудиторная работа способствует формированию нравственных качеств будущих психологов, развития их творческого потенцииала, формированию личностного стиля деятельности и поведения, развития потребности и навыков самообразовательной деятельности, воспитанию здорового образа жизни, развития волевых, лидерских и организаторских качеств.

Ключевые слова: внеаудиторная работа, саморазвитие, саморазвитие, досуг, творчество, студенческое самоуправление.

Надійшла до редакиії: 04.01.2019 p. Прийнята до друку: 25.01.2019 p. 